\title{
Presenting New Construction on Mothering to Indonesian Muslim Millennial Generation through Islamic Books
}

\author{
W Z B Siregar ${ }^{1}$ \\ Universitas Islam Negeri (UIN )Sunan Ampel Surabaya, Surabaya, Jawa Timur \\ Indonesia $^{1}$ \\ \{wahidahzeinsiregar@yahoo.com ${ }^{1}$ \}
}

\begin{abstract}
Discourse on mothering remains central in Muslim society including in Indonesia. Mother is assumed to be the one who responsible for the good attitude and success of her children. This assumption, in the mind of many Muslim people, needs to be sustained, even though many Muslim mothers are now active in public activities. This paper aims to look at discourse on mothering offered by authors of ten Islamic books published in Indonesia. The authors of the ten books offer new construction on mothering not really on the issue they raise but more to the strategies they use. Their opinions are on the contrary to many feminists' perspectives that believe mothering is a socially constructed task, not a merely biological issue. Therefore, anyone can do mothering. Applying ethnographical textual analysis, I raise some questions to these books: what do these authors say about the role of mother? Do they offer certain tips or advice on how to be good mothers? What Islamic texts do they use to strengthen their arguments? In my view the publications of these books are in line with the rise of conservatism within Indonesian Muslims, to bring back Muslim women to what they perceived as the appropriate way to do mothering. Millennial female Muslim generations are basically the targets of these authors.
\end{abstract}

Keywords: New Construction, Mothering, Islamic Books

\section{Introduction}

This paper aims to look at the discussion on mothering offered by some Muslim authors through their books. I saw those books when I entered a bookstore which is prominent not just in my city, Surabaya but also in Indonesia. These books are placed at the front display of that bookstore. Therefore, visitors to the bookstore can easily get and buy those books. Covers of the books are quite eye-catching. Some of the books use color paper such as pink and green, not just blank paper in their writings. I am curious to know what do the authors say about mothering in those books.

I tried to skim some books, looked at their table of contents and read some pages. I saw that the authors of the books are explaining who are good mothers according to Islam. They include verses from the Qur'an and Hadith from the prophet Muhammad to strengthen their opinions. They also gave some examples of good wives in the prophet Muhammad's era. Two books are actually stories of the authors on their mothers. They want to share their good memories of their mothers as wonderful mothers. 
To my knowledge, discourse on mothering, particularly within Western feminism has started al least three decades ago. Nancy Chodorow, for instance, has written a book about mothering entitled "The Reproduction of Mothering: Psychoanalysis and the Sociology of Gender" in 1978. Sara Ruddick wrote "Maternal Thinking" in 1980. Evelyn Nakano Glenn et al edited book entitled "Mothering: Ideology, Experience, and Agency" in 1994. All the books show that mothering is not a task that is given by society to women only because of their biological capacity but more to social construction. As a result, the discourse and attitudes of people toward mothering are influenced by their specific circumstances or historical context.

In Indonesia, discussion on mothering has also run for a long time, up and down according to historical circumstance, initiated by those who categorized as feminist or non-feminist, by Muslim scholars or non-Muslims scholars. Kartini, for instance, has struggled to improve women's lives since the end of the nineteenth century. She was successful in establishing a school for girls but failed to avoid arrange marriage. She died a week after delivering her first child [1]. Her story reflects that at that time, mothering is a must for a woman. But what about now?

Discussions and debates on mothering are continuously going in every phase that Indonesian people have experienced, prior to independence, in the struggle for independence, in the struggle to end authoritarian government led by President Suharto, and at the democratic climate of this time, the reform era. The intensity of the discussions is depended on how much freedom is given by the authority of the country to the society. In general, however, many signs of progress have been achieved by Indonesian women through those discussions even though there are persistent problems. It is for sure that Indonesian women have proven their important contribution to the development of the country [2]. Statistical data shows that in 2017, 46,31 percent of women worked as professionals [3]. In the same year, women's share of the national income reached 36,62 percent [4]. Therefore, when reading thoroughly to those books, I see that the authors do not really count the contributions that women, including Muslim women to the progress that Indonesian people have experienced.

I am interested to know who are the authors of those books? What is the purpose of the authors to write those books? Who are the readers? Is there any special situation that encourages them to write those books? What do they think about mothering? What are their arguments in imposing their ideas on mothering? What are the tips they offer to a woman to be a good mother? To answer these questions, I use an ethnographical textual analysis as explained by Silvermen [5].

\section{Method}

According to Frey, Botan, and Kreps (1999), the purpose of textual analysis to"describe the content, structure, and functions of the messages contained in texts". Text here includes words, images, or words and images [5]. Types of texts are various, such as novels, newspapers and magazines, e-mail messages, official documents, and speech. According to Somekh and Lewin, even color, gesture, and music can also be categorized as texts. These texts contain language, even though it will be questioned whether the language will have the same role as in written texts or different [6]. In this research the text that I look books.

A study on text for social research including research on gender is getting more attractive. If in the previous time, the text is mostly used for strengthening arguments of authors, nowadays, the text itself is studied. It is interesting because unlike interviews, text cannot be intervened by a researcher. It should be explained as they are presented. As Silvermen argues "the role of textual researchers is not to criticize or to assess particular texts in term of 
apparently objective standards. It is rather to analyze how they work to achieve particular effects-to identify the elements used and the functions these play" [5].

There are many methods that can be applied in doing research on text, such as content analysis, global analysis [7]. semiotics or social semiotics [8] content analysis, analysis of narrative structures, ethnography, and ethnomethodology [5]. Many authors argue that content analysis is considered as a quantitative type of research, while other types of textual analysis are categorized as qualitative. But Berg sees content analysis can also be included as a qualitative type of research. As he argued that content analysis is "a passport to listening to the words of the text" [9].

In this research, I classified my method as ethnography as it is explained by Silvermen. He argues that "ethnographers are more concerned with the processes through which texts depict [reality] rather than with whether such texts contain true or false statements" [5]. Some questions raised by the researcher doing ethnography of textual analysis are such as: "how are texts written? How are they read? Who writes them? Who read them? For what purpose? On what occasions? With what outcomes?" [5]. These kinds of questions that I ask to the ten books that I analyze in this research.

Those ten books are:

1. El-Bantanie, M S, Menjadi Bunda yang Dirindukan: Berkesan, Cerdas, dan Mendidik-Being Missed Mother: Impressible, Smart, and Educating, Jakarta: PT Elex Media Komputindo, 2018.

2. Rosul, M, Ibu: Jalan Tengah Menuju Surga-Mother: Middle Pathway to Go to Heaven, Jakarta: PT Elex Media Komputindo, 2018.

3. Cholik, A, Madrasah Itu Bernama Ibu: 40 Kiat Menjadi Wanita Hebat-That School Called Mother: 40 tips to be Great Woman, Jakarta: PT Elex Media Komputindo, 2016.

4. Khaeron, N, Pesan Terakhir Ibu: Cinta yang Tak Pernah Berakhir-the Last Message from Mother: Love that will never End, Solo: Tinta Medina, 2018

5. Amiruddin, A, Muliakan Ibumu-Honoured Your Mother, Bandung: Khazanah Intelektual, 2016.

6. Jayana, T.A, Ketika Ibu Telah Tiada: Sebuah Renungan Tentang Kemahadayaan Seorang Ibu-When Mother Has Already Passed Away: A Reflection on The Powerfuf of Mother, Jakarta: PT Elex Media Komputindo, 2014.

7. Akbar, F, Be the Best Wife: Bagaimana menjadi Istri dan Ibu yang Terbaik? Dilengkapi Tips Mengelola Keuangan \& Resep Masakan Harian Keluarga-Be the Best Wife: How to be the Best Wife and Mother: Supplemented with Tips to Manage Family Financial \& Recipes for Family Daily Cook, Yogyakarta: Pro-U Media, 2017.

8. Harits, U dan Irfan S, Dahsyatnya menjadi Ibu Rumah Tangga: Suami Bangga, Keluarga Sehat, Pendapatan Meningkat-The Greatness of Being Housewives: Husband is Proud, Family is Healthy, Income are Higher, Surakarta: Cinta, 2011

9. Fadjaray, S, Berseri sebagai Istri Berilmu sebagai Ibu: Inspirasi Peran Mulia Wanita Penyejuk Jiwa Membangun Generasi Cerdas Mulia-Glowing as Wife, Knowledgeable as Mother: Inspirations for Honourable Role of Women, Cooling Soul Develop Smart and Respectable Generation, Sidoarjo: CV Growin, 2016

10. Takariawan, C, Wonderful Wife: Menjadi Istri Disayang Suami-Wonderful Wife: Being Wife Who will be Loved by Husband, Surakarta: Era Adicitra Intermedia, 2018. 


\section{Result and Discussion}

As I mention previously, looking at their physical performance, those books are quite attractive. Five out of the ten: El-Bantanie, Rosul, Khoeron, Akbar, and Takariawan, are covered with pink color. The book cover of Rosul has an animation picture showing a hijabwearing mother hugging her daughter. Both mother and daughter are circled with the animated picture of love (heart) with flowers as its line. Three books are in blue. Those are Cholik, Jayana, and Amiruddin's. Book of Amiruddin is covered with a painting picture of an elderly woman wearing a hijab, sitting on a chair that is sited close to the window. At the right bottom of this book, there is a sentence that is put inside a circle states: "Lengkap dengan tata cara memuliakan ibu serta tips menjadi ibu yang pantas dimuliakan"-Accomplished with guides to honor mother and tips to be the mother that is appropriate to be honored. One book is purple in Colour which is Fadjaray's book. Another one is in white cover and a picture of vegetables, dominantly red tomatoes placed in the right corner. That is a book that of Harith and Supandi.

Those ten books share a similar aim, which is to guide Muslim women to be good mothers. But they use different strategies. There are eight strategies that they use. The first is by explaining who are mothers and what kind of fortunate that women will get by being a mother and performing mothering appropriately. Four books, those of Rosul, Akbar, Harits and Supandi, and Fadjaray start their chapters by explaining who is mother and specialty they have.

The second is by telling that to be a good mother, a woman herself has to be good first. Book of El-Bantanie and Akbar do this. El-Bantanie, for instance, stated "The first effort that a mother needs to do in educating her child is by being good herself firstly. How can a mother teach good ethics and devotions if she herself does not have good ethics and devotion?" [10]. Akbar states: "A great woman is behind a husband and the first school of her children. Therefore, since an early age, sharpen your mothering potency and your maturity" [11].

The third is through giving advice that the authors got from their own mothers. For example, Khoeron clearly mentions in his book that the advice he shares in his book are extracted from the advice that his mother gave him. As he states, "honestly, advice that I mention in this book is obtained from advice that my mother gave me, so I dedicate this book to her" [10]. There are 48 advices that he shares in his book.

The fourth is through giving advice directly to the readers of the book. These books are books of Jayana, Cholik, El-Bantanie, Akbar, Harits and Supandi, and Fadjaray. Those advices are quite various. In total, there are more than 200 advices they share to the readers. Someof the advices are similar, but more are different. Similarities, for instance, can be found in advice that a mother should cook for her children and husband. The authors use different terminologies or short phrases in explaining this advice. Cholik uses the term "Great Chef [12] Khoeron makes a sentence, "There is love in her cooking" [13]. El-Bantanie uses "miss my mother's cook" [10]. Akbar uses "More delicious mother's cook". She even gives eight food recipes that can be practiced by young [11]. Another similarity is when the authors telling that a mother should be smart or intelligent. These are the book of El Bantanie and Fadjaray. ElBantanie states "Being a smart mother" [10]. Fadjaray says "Having knowledge as a mother" [14].

The fifth is by showing examples of negative impacts that mothers can give to their children if a mother is not a good mother. Fadjaray states, we would like to see a mother, especially pregnant mother to have strong faith to Allah. Her sadness and happiness will be reported to Allah, not to paranormal, shaman, and others media of polytheism. By doing this, we educate the mother and her unborn baby to perform faithful to Allah, not to duplicate Him, 
practicing polytheism " [14]. El-Bantanie proposed a question, how can a mother ask her children to be honest, when she herself is a liar [10].

The sixth, by showing examples of great mothers in the Prophet Muhammad's era. Fadjaray mentions Siti Hajar, the wife of Prophet Ibrahim as an example of a great mother and wife [14]. Harits and Supandi mention Siti Muthi'ah, Fatimah, and Asma binti Abu Bakar. Siti Muthi'ah is well known for her obedience to her husband. Fatimah is the daughter of the prophet Muhammad. She is important to care for the prophet, popular with her patient in doing his duties. In addition, Asma is the daughter of Abu Bakar, a close friend of the Prophet Muhammad. She is known as a brave woman. She joined the warriors of Islam in the battle of Yarmuk to fight for the enemies of Islam [15].

The seventh is by illustrating the strong impact of a mother's anger or satisfaction toward her children. In particular, a mother should avoid anger for her children in order to make the children having a good life. Jayana takes this strategy. He mentions stories about Al Qamah, a friend of the Prophet Muhammad. Al Qamah is a pious person. One day he was very sick and dying. But his mother's anger to him makes him suffer. Al Qamah could finally die after her mother forgave his mistakes. Jayana also tells the story about Uwais Al-Qarni who loves his mother very much and always cares for her. His mother was an unhealthy lady. But, she always felt happy because of her son's attention and care. His mother's satisfaction to him makes Uwais be a man who was entitled by the Prophet Muhammad as a resident of the sky, not the earth, reflecting his higher position in heaven [16].

The eighth is by describing the bad impacts of the idea of women's emancipation and feminism to Muslim women and society. This is stated explicitly by Harits and Supandi:

I feel it is not easy for an ordinary woman like me to fight a strong wave of emancipation that at the present time insists women be equal with men, between Eve and Adam that exceed the women's nature... how sharp is the speaking and writing of those who want to reduce Islamic values from the soul of Muslim society? With support fundings from aids, they widespread humanism, and feminism to the reference of Muslim society. Hence, many Muslim scholars are deceived by their ideas. Huge numbers of Muslim academics who got tongue ache, not being able to speak about the value of Islam on women. Their pens are stack, cannot write Islamic ideas on women [15].

In relation to verses of $\mathrm{Al}$ Qur'an and Hadits that are used by the authors to strengthen their arguments, there are also various styles. Six books, those of El-Bantanie, Rosul, Cholik, Khoeron, Akbar, Harits and Supandi do not mention Arabic texts of the verses and Hadits as well as their Indonesian texts, but quote them indirectly or mention them implicitly. One book, that of Fadjaray does not put the Arabic or Indonesian texts of Al Qur'an's verses and Hadits directly, but putting the translation of the verses and Hadits. In other words, we do not see Arabic letters in his book. The other three books, those of Amiruddin, Jayana, and Harits and Supandi, use the verses and Hadits in Arabic text.

The verses and Hadits used by the authors are depended on the topics they discussed. But for the Hadits, many authors use Hadits as told by Ibnu Majah: when the Prophet Muhammad was asked by one of his friends, who should I respect at first, he answered your mother, his friend asked him again, who is next, he answered your mother, his friend asked him again, who is next, he answered again, your mother, his friend asked him again, who is next, he this time answer, your father.

In my view, readers of these books are Muslim women, particularly those who have young or teenage children. These Muslim young mothers are the millennial generation which is defined as those who are born between 1981 and 1996, in age 23 to 38 at the present [17]. This is reflected in the way they write the text. Look at the extract that I take from the book of 
El-Bantanie, have you ever experience that one day, after cooking your children's favorite foods, your children refuse the invitation of her/his friend to eat in a modern restaurant? $\mathrm{He} / \mathrm{she}$ prefer to eat her favorite food that you cook at home. Your homemade foods can become a bond between you and your children. There is proof of love that you give to your children in your cooking [10].

These books imply the argument that home is a better place for women. They actually realize that the economic contribution of women to their families. But, they do not agree if women put their works as their priority. See, for instance, the title of a chapter in Amiruddin's book: "Ibu Bekerja Harus Datangkan Berkah Bukan Petaka"-a mother who works or has a career outside the home should bring fortune to their family, not a misery. Amiruddin suggests that to combine these two works, a mother can establish work from homes such as opening stall at home or catering services. Harits and Supandi suggest some other professions such as doctors for women only, midwives, teachers of pre-schools and child care or kindergarten to female students only, laundry service, and so on. In other words, a profession that is suitable for women, or the same works that they do at home but extended to others. Therefore, the sexual division of labor is transparently seen in their perspectives.

I myself do not have enough knowledge about who these authors are. How popular they are in Indonesian society. I know there are many Indonesian Muslim scholars who write books about women in Islam, such as Shihab, M.Q; Umar, N; Subhan, Z, and Hasyim, S, to name a few. But those books are academic books that may be read-only by those studying at the universities. These new constructions book in my view do not target the academic community but directly to the millennial generation. Bookstore may not really think about who the authors and the readers of the books. As a business institution, a bookstore may just think about how the store will get benefit from the books it sells. Authors who want to spread the idea of purity of Islam use the chance smartly.

Those books, in my view, are an encounter with feminism. They are trying to offer new construction on mothering, not necessarily mean new in the idea but new in terms of bringing back past discourse to the present time, using available space they get from the era of reform in Indonesia. After the fall of the authoritarian government under Suharto's presidency, Indonesian people have more freedom to express their opinions. Those who have a conservative view on women take the opportunity to put forward their perspectives. They become agents for an effort to bring Muslim society to return to Islam as practiced in the Prophet Muhammad's era.

Mothering is still a contested area. It is constructed by men as well as women in specific historical situations. But women are not a homogeneous entity. Those books see mothers as in a normal condition such as those who have husbands with enough income to feed them and their children. Oh, argues that an accurate portrayal of women particularly on mothering is important in order to understand their daily real situation. Quite often people are asked to differentiate good and bad mothers without enough understanding of the mothers' actual experience [18].To understand what is mothering wide and deeply, understanding differences among women is necessary. It is the same for understanding the mothering of Muslim women. As Pappano and Olwan argue, "it is important to note that there is no singular way in which Muslim mothers mother. Nor is there a unified way in which Muslim women engage in or disengage from the social institution of motherhood" [19]. 


\section{Conclusion}

This research shows that authors of the ten books that I analyze using ethnography textual analysis are trying to put forward their ideas on mothering in order to make Indonesian Muslim women be good mothers. Particularly those mothers who are categorized as millennial generations. They create books to be attractive in their outlook, hence visitors of the bookstore are willing to buy and read those books. Hence, their ideas will be adopted.

There are eight strategies used to achieve the aim, starting from explaining what is the essence of being a mother up to attacking feminism as an intruder to women and society in general. They even attack Muslim scholars for being influenced by feminism and emancipation. They want Muslim women to perform Islam purely as in the Prophet Muhammad's era. They use verses of the Qur'an and Hadits to strengthen their arguments.

These books reflect that mothering is still an important topic to be discussed. It is a debatable concept in the past and in the present time. Life of women, the situation they face, are changing over time, and it is so with the life of people in general. However, social construction on mothering is still very strongly prevent by society, including Muslim society. Authors of those books to the same extent look likes proposing new construction on women, but they are actually talking about the ideal portrayal of a good mother with less consideration on the real situation that women face in their daily life.

Women are not a homogeneous group. They are different in culture, history, and experience. The social and political atmosphere of their country is contributed to the intensity of debates on mothering. Indonesia at the present time is a democratic country that provides more freedom to its people to express their opinions. These authors use the opportunity to widen their idea of mothering. Further research is needed to find out what actually the readers think about those kinds of books.

\section{References}

[1] R. . Kartini, Habis Gelap Terbitlah Terang-After Dark Comes Light. Yogyakarta: Penerbit Narasi, 2018.

[2] W. Siregar, Gaining Representation in Parliament: A Study on the Struggle of Indonesian Women to Increase their Numbers in Parliaments in The 2004 Elections. Saarbrucken: Lambert Academic Publishing, 2010.

[3] Badan Pusat Statistik, "Perempuan sebagai Tenaga Profesional Menurut Provinsi, 2010-2018," 2018.

[4] Badan Pusat Statistik, "Sumbangan Pendapatan Perempuan menurut Provinsi, 20102018," 2018.

[5] D. Silvermen, Interpreting Qualitative Data: Methods for Analysing Talk, Text and Interaction. London: Sage Publications, 2005.

[6] C. Lewin, Research Methods in the Social Sciences. London: Sage Publications, 2007.

[7] U. Flick, An Introduction to Qualitative Research. London: Sage Publications, 1999.

[8] D. Kress, C and Mavers, Social Semiotics and Multimodal Texts. London: Sage Publications, 2007.

[9] B. . Berg, Qualitative Research Methods for the Social Sciences. Boston: Allyn and Bacon, 1998.

[10] M. S. El-Bantanie, Menjadi Bunda yang Dirindukan: Berkesan, Cerdas, dan Mendidik. Jakarta: PT Elex Media Komputindo, 2018. 
[11] F. Akbar, Be the Best Wife: Bagaimana menjadi Istri dan Ibu yang Terbaik? Dilengkapi Tips Mengelola Keuangan \& Resep Masakan Harian Keluarga. Yogyakarta: Pro-U Media, 2017.

[12] A. Cholik, "Madrasah Itu Bernama Ibu," in 40 Kiat Menjadi Wanita Hebat, Jakarta: PT Elex Media Komputindo, 2016.

[13] N. Khaeron, Pesan Terakhir Ibu: Cinta yang Tak Pernah Berakhir. Solo: Tinta Medina, 2018.

[14] S. Fadjaray, Berseri sebagai Istri Berilmu sebagai Ibu: Inspirasi Peran Mulia Wanita Penyejuk Jiwa Membangun Generasi Cerdas Mulia. Sidoarjo: CV Growin, 2016.

[15] U. dan I. S. Harits, Dahsyatnya menjadi Ibu Rumah Tangga: Suami Bangga, Keluarga Sehat, Pendapatan Meningkat. Surakarta: Cinta, 2011.

[16] T. . Jayana, Ketika Ibu Telah Tiada: Sebuah Renungan Tentang Kemahadayaan Seorang Ibu. Jakarta: PT Elex Media Komputindo, 2014.

[17] Pew Research Centre, "Defining Generations: Where Millennials end Generation Z Begins," 2019. .

[18] I. Oh, "Motherhood in Christianity and Islam: Critiques, Realities, and Possibilities," J. Relig. Ethics, vol. 38, no. 4, pp. 638-653, 2010.

[19] D. . Pappano, M.A and Olwan, "Introduction', in Pappano, M.A and Olwan, D.M (eds), Muslim Mothering," in Global Histories, Theories, and Practices, Bradford: Demeter Press, 2016, pp. 1-17. 